5. Anderson BJ, Allegaert K, Van Den Anker JN, Cossey V, Holford NHG. (2006). Vancomycin pharmacokinetics in preterm neonates and the prediction of adult clearance. Br J Clin Pharmacol;63(1):75-84.

6. Germovsek E, Osborne L, Gunaratnam F, Lounis SA, Busquets FB, Sinha AK. (2019). Development and external evaluation of a population pharmacokinetic model for continuous and intermittent administration of vancomycin in neonates and infants using prospectively collected data. J Antimicrob Chemother, 1-9.

Disclosure(s) R. Keizer is an employee and stockholder of InsightRX.

\section{P100 A PRACTICAL FRAMEWORK FOR THE ASSESSMENT OF RISKS AND BENEFITS OF OFF-LABEL PRESCRIBING IN PAEDIATRICS (ARBOP-P)}

\begin{abstract}
1,2,3 TM Van der Zanden*, ${ }^{4} \mathrm{NJ}$ Vet, ${ }^{3,4,5} \mathrm{SN}$ de Wildt. ${ }^{1}$ Department of Paediatrics, Erasmus MC - Sophia Childrens Hospital, Rotterdam; ${ }^{2}$ Department of Pharmacology and Toxicology, Radboud University Medical Center, Radboud Institute for Health Sciences, Nijmegen; ${ }^{3}$ Dutch Knowledge Center Pharmacotherapy for Children, Den Haag; ${ }^{4}$ Department of Paediatric Surgery, Erasmus MC - Sophia Childrens Hospital, Rotterdam; ${ }^{5}$ Department of Pharmacology and Toxicology, Radboud Institute for Molecular Life Sciences, Nijmegen, The Netherlands
\end{abstract}

\subsection{6/archdischild-2019-esdppp.138}

Background Guidelines for off-label prescribing are emerging. ${ }^{1-6}$ However, these guidelines do not provide practical guidance to assess the risk benefit balance and select the right paediatric dose We, therefore, aimed to develop a practical framework to guide paediatric healthcare professionals to assess the risks and benefits of off-label use.

Methods We have reviewed available literature on the suggested criteria for appropriate off-label use and evaluated these criteria for relevance in paediatrics. For guidance on doseselection we searched for regulatory guidance on paediatric drug development. Next, the literature was searched for strategies that can be applied to assess the risks and benefits of off-label use. Based on literature findings a framework was proposed to provide practical guidance to physicians for offlabel prescribing. Finally, the framework was applied to a case.

Results The following conditions for appropriate off-label use were identified based on available literature: 1. Medical need for off-label use. 2. Off-label use is based on 'high quality evidence'. As 'high quality evidence' in paediatrics is often lacking-, we propose to replace the need for high quality evidence by a positive risk-benefit assessment based on available evidence. 3. Parents and patients are informed. This is not feasible for every single drug prescribed off-label, we propose a graded approach 4. The outcomes of off-label use are followed up.

The PROACT-URL framework ${ }^{7}$ for decision-making as well as the FDA paediatric decision tree ${ }^{8}$ seem helpful tools to guide decisions in real-life practice.

Conclusion We identified important aspects and tools to develop a framework (ARBOP-P) to guide healthcare professionals on how to systematically assess and balance the benefits and risks for off-label use, including dose selection, to ultimately optimize efficacy and safety of paediatric off-label prescribing.

\section{REFERENCES}

1. Frattarelli DA, Galinkin JL, Green TP, et al. Off-label use of drugs in children. Pediatrics 2014;133:563-7 Online.

2. Dooms M, Killick J. Off-label use of medicines: The need for good practice guidelines. Int J Risk Saf Med. 2017;29:17-23 Online.
3. Gazarian M, Kelly M, McPhee JR, Graudins LV, Ward RL, Campbell TJ. Off-label use of medicines: consensus recommendations for evaluating appropriateness. Med J Aust 2006;185:544-8 Online.

4. Largent EA, Miller FG, Pearson SD. Going off-label without venturing off-course: evidence and ethical off-label prescribing. Arch Intern Med 2009;169:1745-7 Online.

5. Ansani N, Sirio C, Smitherman $T$, et al. Designing a strategy to promote safe, innovative off-label use of medications. Am J Med Qual 2006;21:255-61 Online.

6. Weda M, Hoebert J, Vervloet $M$, et al. Study on the off-label use of medicinal products in the European Union.: www.ec.europa.com 2017.

7. Hammond J, Keeney R, Raiffa H. Smart Choices:A practical guide to making better decisions. Boston, MA.: Harvard Business School Press.; 2002.

8. Dunne J, Rodriguez WJ, Murphy MD, et al. Extrapolation of adult data and other data in pediatric drug-development programs. Pediatrics. 2011;128:e1242-9 Online.

Disclosure(s) Nothing to disclose

\section{P101 EXTENDING THE DUTCH PAEDIATRIC FORMULARY ACROSS EUROPE: SUCCESSFUL DEVELOPMENT OF COUNTRY SPECIFIC, PARALLEL, PAEDIATRIC DRUG FORMULARIES}

\begin{abstract}
${ }^{1,2,3} \mathrm{~T}$ Van der Zanden ${ }^{*},{ }^{4} \mathrm{~A}$ Neubert, ${ }^{4} \mathrm{~J} Z a h n,{ }^{4} \mathrm{~S}$ Wimmer, ${ }^{5} \mathrm{M}$ de Hoop, ${ }^{6,7} \mathrm{~T}$ Rosness, ${ }^{8} \mathrm{C}$ Kjeldby-Høie, ${ }^{9,10} \mathrm{~A}$ Teigen, ${ }^{11} \mathrm{C}$ Male, ${ }^{11} \mathrm{E}$ Rauch, ${ }^{12} \mathrm{~F}$ Lagler, ${ }^{4} \mathrm{~W}$ Rascher, ${ }^{2,3,13} \mathrm{~S}$ de Wildt. 'Department of Paediatrics, Erasmus MC - Sophia Childrens Hospital, Rotterdam; ${ }^{2}$ Department of Pharmacology and Toxicology, Radboud University Medical Center, Radboud Institute for Health Sciences, Nijmegen; ${ }^{3}$ Dutch Knowledge Center Pharmacotherapy for Children, Den Haag, The Netherlands; ${ }^{4}$ Department of Paediatrics and Adolescents Medicine, Universitätsklinikum Erlangen, Erlangen, Germany; ${ }^{5}$ KNMP, Den Haag, The Netherlands; ${ }^{6}$ The Norwegian Medicines Manual for Health Personnel; ${ }^{7}$ The Faculty of Mathematics and Natural Sciences, School of Pharmacy; ${ }^{8}$ Sykehusapoteket, Rikshospitalet, Oslo; ${ }^{9}$ Sykehusapoteka Vest HF, Stavanger; ${ }^{10}$ Medicines for Children Network, Bergen, Norway; ${ }^{11}$ Department of Paediatrics, Medical University Vienna, Vienna; ${ }^{12}$ Institute for Inborn Errors of Metabolism, Paracelsus Medical University, Salzburg, Austria; ${ }^{13}$ Department of Paediatric Surgery, Erasmus MC - Sophia Childrens Hospital, Rotterdam, The Netherlands
\end{abstract}

\subsection{6/archdischild-2019-esdppp.139}

Backgrounds As many drugs in paediatrics are used of off-label, prescribers across Europe face a lack of evidence-based dosing guidelines. The Dutch Paediatric Formulary (DPF) was developed to provide dosing guidelines based on best available evidence from registration data, investigator-initiated research, clinical experience and consensus (1). The DPF has recently joined forces with Germany, Norway and Austria aiming to develop multi-language, parallel, paediatric drug formularies based on the DPF.

Methods

The DPF database and ICT framework were extended to a duplicate database for Germany. The dosing guidelines were translated to German and reviewed for fit with German practice. Relevant drugs and dosing recommendations were selected and country-specific information was added to address country-specific needs. Work-sharing on content development was studied in a small pilot.

Results The German Pediatric Formulary (www.kinderformularium.de) was launched on 1 October 2018 within a German paediatric medication safety project (KiDSafe). At that time 119 of 769 drugs were reviewed and published in the German formulary.The dosing recommendations of the DPF show a good fit with German practice; i.e. adaptations were needed in less than $10 \%$ of the cases caused by differences in licensing status, national guidelines or availability of formulations. There were no differences in interpretation of evidence. Nine drugs - highly relevant for German practice, but not listed in the DPF, were added to the German formulary based on SmPC. The content 
work sharing was piloted by the development of a new monograph and the periodic revision of a monograph complying to the Dutch standard operating procedure by Germany. This pilot has shown the feasibility of work-sharing in developing and updating drug monographs.

Conclusion The Dutch framework has successfully been extended to the German situation. Work-sharing on the development of dosing recommendations is feasible. Similar extension to Norwegian and Austrian nation-wide formularies has started.

\section{REFERENCES}

1. van der Zanden $T$, De Wildt $S$, Liem $T$, Offringa $M$, de Hoog M. Developing a pediatric formulary for the netherlands. Arch Dis Child 2017;Apr;102(4):357-61.

Disclosure(s) Tjitske van der Zanden is managing director of the Dutch Paediatric Pharmacotherapy Expertise Network; Saskia de Wildt is medical director of Dutch Paediatric Pharmacotherapy Expertise Network. The other authors have no financial disclosures relevant to this article.

\section{P102 ALTERNATIVE SPLICING OF THE SLC01B1 TRANSPORTER IN PAEDIATRIC LIVER}

${ }^{1} \mathrm{BD}$ van Groen*, ${ }^{2} \mathrm{C} B \mathrm{Bi}^{2}{ }^{2} \mathrm{R}$ Gaedigk, ${ }^{2} \mathrm{~V}$ Staggs, ${ }^{1} \mathrm{D}$ Tibboel, ${ }^{1,3} \mathrm{SN}$ de Wildt, ${ }^{2} \mathrm{JS}$ Leeder ${ }^{1}$ Erasmus MC - Sophia Children's Hospital, Rotterdam, The Netherlands; ${ }^{2}$ Children's Mercy Hospital, Kansas City, MO, USA; ${ }^{3}$ Radboudumc, Nijmegen, The Netherlands

\subsection{6/archdischild-2019-esdppp. 140}

Background Alternative mRNA transcripts occur in $>90 \%$ of human genes and may be triggered by developmental signals. The hepatic transporter OATP1B1 (gene name SLCO1B1) traffics substrates across the hepatic membrane, and shows agerelated changes in protein expression. We aimed to predict novel isoforms of OATP1B1 by studying alternative splicing of SLCO1B1 in human paediatric post-mortem liver tissue, and the relationship of their mRNA expression with age.

Methods mRNA expression of SLCO1B1 transcripts was determined using RNA sequencing (HISAT2/StringTie). Novel mRNA transcripts were considered of relevance when (1) the expression was $>5 \%$ of the annotated isoform, (2) it was a SLCO1B7 and SCLO1B1 hybrid transcript, or (3) when the expression was associated with age. The software packages ORF-finder, TMpred and TOPO2 were used to predict the protein sequence and structure of the novel isoforms. Relationship of expression with age was studied with the KruskalWallis test for age groups (fetal, 0-1.5 year, 1.5-6 year, 6-12 year and 12-18 year) and with Spearman correlation tests for age on continuous scale.

Results In 97 hepatic post-mortem tissues (gestational age median 16.4 [range 14.7-41.3] weeks, postnatal age 0.36 [0 17] years) 27 novel mRNA transcripts were detected. Of these, 13 were relevant: 2 isoforms are predicted to translate into amino acid sequences similar to the annotated isoform for OATP1B1, 9 isoforms may translate into truncated versions, and the expression of 8 isoforms was associated with age. None of the isoforms had an ORF that covered the SLCO1B7 region.

Conclusion We showed that novel SLCO1B1 mRNA isoforms potentially translate into OATP1B1 protein with unknown function, and that alternative splicing may well be a regulatory mechanism for SLCO1B1 expression during development. This data provides a better understanding of age-related changes in the expression of OATP1B1, and, with that, potentially improves prediction of disposition of endogenous and exogenous substrates.

Disclosure(s) BG was supported, in part, by the Ter Meulen fund 2018 provided by the Royal Dutch Academy of Sciences. The National Institute of Child Health and Human Development Brain and Tissue Bank for Developmental Disorders at the University of Maryland is funded by the National Institutes of Health (NIH) contract HHSN275200900011C, reference number, N01-HD-9-0011 and the Liver Tissue Cell Distribution System is funded by NIH contract number N01DK-7-0004/HHSN267200700004C.

\section{P103 TARGET ATTAINMENT OF AMIKACIN THERAPY IN CRITICALLY ILL CHILDREN}

1J Verbruggen*, ${ }^{2} \mathrm{~K}$ Jakipbayeva, ${ }^{1,2} \mathrm{~T}$ Van Der Heggen, ${ }^{2,3} \mathrm{E}$ Dhont, ${ }^{2} \mathrm{~L}$ Dhondt, ${ }^{4,5}$ J Vande Walle, ${ }^{6,7} \mathrm{P}$ De Paepe, ${ }^{8} \mathrm{H}$ Herck, ${ }^{2,3,4} \mathrm{P}$ De Cock. ${ }^{1}$ Department of Pediatrics, Ghent University Hospital; ${ }^{2}$ Heymans Institute Of Pharmacology, Ghent University; ${ }^{3}$ Department of Pediatric Intensive Care, Ghent University Hospital; ${ }^{4}$ Department of Internal Medicine and Pediatrics, Ghent University; ${ }^{5}$ Department of Pediatric Nephrology; ${ }^{6}$ Department of Emergency Medicine, Ghent University Hospital; ${ }^{7}$ Department of Basic and Applied Medical Sciences, Ghent University; ${ }^{8}$ Department of Cardiac Intensive Care, Ghent University Hospital, Ghent, Belgium

\subsection{6/archdischild-2019-esdppp.141}

Background Research regarding the optimal amikacin (AMI) dosing regimen in critically ill children is scarce. ${ }^{1}$ Optimal AMI efficacy has been observed with plasma peak over minimal inhibitory concentration of the suspected pathogen (peak/ $\mathrm{MIC})$ ratios of 8 to 10 . Plasma trough levels $\left(\mathrm{C}_{\min }\right)>5 \mathrm{mcg} /$ $\mathrm{ml}$ are related to its toxicity.

The objectives of this pilot study were to: (1) evaluate target attainment rate and occurrence of supratherapeutic concentrations in early and assumed steady-state dose conditions, and (2) investigate the correlation between AMI clearance and estimated glomerular filtration (eGFR).

Methods Children admitted to the ICU receiving intravenous AMI $(20 \mathrm{mg} / \mathrm{kg}$ once daily) were included. Serial blood samples were obtained from early (1st/2nd) and assumed steadystate (SS) doses. The evaluated target peak concentration range was $54-64 \mathrm{mcg} / \mathrm{ml}$, assuming a Pseudomonas aeruginosa infection with Eucast MIC breakpoint of $8 \mathrm{mg} / \mathrm{L}$, and a $\mathrm{C}_{\text {min }}$ threshold of $5 \mathrm{mcg} / \mathrm{L}$. eGFR was estimated using the modified Schwartz formula. AMI clearance was calculated using noncompartmental PK analysis. Correlation was assessed by means of a scatter plot and Pearson Correlation Coefficient ( $r$ ).

Results

Twenty-one patients (median age 1,5 years; range:0,5 months14 year, median eGFR $162 \mathrm{ml} / \mathrm{min} / 1,73 \mathrm{~m}^{2}$ (range: $107-475$ $\mathrm{ml} / \mathrm{min} / 1,73 \mathrm{~m} 2$ ) were included. In early dose conditions, $69 \%$ of patients had therapeutic peak concentrations (median: 60 $\mathrm{mcg} / \mathrm{ml}$; range: $26-73 \mathrm{mcg} / \mathrm{ml}$ ). In SS conditions, $60 \%$ of patients had therapeutic peak concentrations (median: $59 \mathrm{mcg}$ / $\mathrm{ml}$; range:35-83 $\mathrm{mcg} / \mathrm{ml}$ ). Only one supratherapeutic $\mathrm{C}_{\min }$ was observed. AMI clearance (median $0.08 \mathrm{~L} / \mathrm{h} / \mathrm{kg}$; range: $0.05-$ $0.91 \mathrm{~L} / \mathrm{h} / \mathrm{kg}$ ) was comparable to what has been previously reported but showed no correlation with eGFR $(\mathrm{r}=0.1$; $\mathrm{p}=0,66)[1]$.

Conclusion This pilot study suggest that the current AMI dosing regimen may lead to subtherapeutic concentrations in patients infected with less susceptible pathogens. Supratherapeutic Cmin were far less of a concern. Dose adjustments of 